\title{
Migration of chlorinated hydrocarbons in multilayer unconsolidated porous media: a case study from the Po Plain, Italy
}

\section{Migrazione di idrocarburi clorurati in mezzi porosi multistrato non consolidati: un caso di studio dalla Pianura Padana}

\author{
Maria Filippini
}

Riassunto: I solventi clorurati sono i contaminanti organici più ubiquitari nelle acque sotterranee da sei decadi a questa parte. A causa del loro elevato grado di tossicità/cancerogenicità e della loro mobilità relativamente elevata e persistenza negli acquiferi, questi contaminanti rappresentano una seria minaccia nei confronti della salute umana e dell'ambiente. I solventi clorurati raggiungono generalmente le falde sotto forma di Dense NonAqueous Phase Liquid (DNAPL), una fase in grado di migrare attraverso acquiferi ed acquitardi in modo molto più rapido e pervasivo rispetto ai contaminanti in fase disciolta. La complessa partizione multifase a cui possono essere sottoposti i solventi clorurati (dalla fase DNAPL a quella disciolta, gassosa o adsorbita), così come la loro trasformazione (es. degradazione), dipendono dalle proprietà fisico-chimiche dei composti stessi ma anche dalle caratteristiche del sistema idrogeologico in cui si trovano a migrare. Nell'ambito del presente lavoro, è stato investigato il sistema idrogeologico al di sotto della città di Ferrara (Pianura Padana), il quale è interessato da contaminazione da solventi clorurati in numerosi siti. In particolare, è stato selezionato un sito pilota, conosciuto come "Sito Caretti", in cui è stato applicato un approccio investigativo ad alta risoluzione e limitato nello spazio. In tale sito sono state raccolte molteplici informazioni ad alta risoluzione spaziale lungo profili verticali (dati stratigrafici, carichi idraulici, composizione idrochimica dell'acqua, isotopi stabili dell'acqua e di contaminanti), attraverso l'utilizzo di sistemi multilivello ed altre tecniche innovative di campionamento ed analisi. Gli obiettivi principali della ricerca erano quelli di

Keywords: chlorinated solvents, intrinsic vulnerability, aquitard integrity, reductive dechlorination, multilevel systems.

Parole chiave: solventi clorurati, vulnerabilità intrinseca, integrità degli acquitardi, declorurazione riduttiva, sistemi multilivello.

\author{
Maria FILIPPINI 莑" \\ Department of Biological, Geological and Environmental Sciences \\ Alma Mater Studiorum University of Bologna \\ via Zamboni 67, 40126 Bologna, Italy \\ maria.filippini3@unibo.it
}

Ricevuto/Received: 01 October 2017-Accettato/Accepted: 03 November 2017 Pubblicato online/Published online: 12 December 2017

This is an open access article under the CC BY-NC-ND license: http://creativecommons.org/licenses/by-nc-nd/4.0/

(C) Associazione Acque Sotterranee 2017 stimare la vulnerabilità intrinseca degli acquiferi e di ricostruire le dinamiche di migrazione e trasformazione dei contaminanti clorurati in relazione alle caratteristiche del mezzo poroso ospitante. Gli acquiferi confinati sono risultati essere maggiormente vulnerabili ai contaminanti in fase DNAPL rispetto a contaminanti in fase acquosa, a causa della presenza di microfratture nei soprastanti acqutardi argillosi. Inoltre, la presenza di livelli ad alto contenuto di materia organica nella stratigrafia locale ha aumentato il potenziale biodegradativo del sistema nei confronti degli eteni clorurati, causando accumuli di Cloruro di Vinile. I risultati ottenuti sono utili non solo alla scala locale, es. per interpretare l'origine della contaminazione in altri siti sul territorio ferrarese, ma anche alla scala globale, al fine di indirizzare future azioni di protezione e bonifica in simili contesti idrogeologici.

Abstract: Chlorinated solvents are the most ubiquitous organic contaminants found in groundwater since the last six decades. Due to their bigh degree of carcinogenicity/toxicity and the relatively high mobility and persistence, they represent a serious threat against the buman health and the environment. These contaminants generally reach groundwater as Dense Non-Aqueous Phase Liquid (DNAPL) that can migrate through aquifers easier than aqueous contaminants. The complex phase partitioning to which chlorinated solvent DNAPLs can undergo (i.e. to the dissolved, vapor or sorbed phase), as well as their transformations (e.g. degradation), depend on the physico-chemical properties of the contaminants and on the features of the hydrogeological system in which they migrate. The hydrogeologic setting below the city of Ferrara (Po plain, northern Italy), which is affected by scattered contamination by chlorinated solvents, has been investigated. In particular, a limited-inspace high-resolution investigation was performed in one selected contaminated test-site, known as "Caretti site". Here, high-resolution vertical profiling of different kind of data (i.e. stratigraphic data, bydraulic heads, bydrochemical composition of water, stable isotopes of water and contaminants) were collected by means of multilevel monitoring systems and other innovative sampling and analytical techniques. The main goals of the research were to assess the intrinsic vulnerability of the aquifers and to identify the dynamics of migration and transformation of the chloroethene contaminants in relationship to the features of the hosting porous medium. The confined aquifers turned out to be more vulnerable to DNAPLs than aqueous contaminants due to the occurrence of microfractures in the overlying clayey aquitards. The presence of organic-rich deposits in the local stratigraphy enhanced the biodegradation of chloroethenes causing accumulation of Vinyl Chloride.

The results are useful at the local scale, e.g. to interpret the origin of contamination in other sites of the Ferrara area, and also at the global scale, to better address future remediation and protection actions in similar settings. 


\section{Introduction}

Alluvial plains constitute both the most human affected portion of earth's surface and the main fresh groundwater reservoir of the planet (Jones 2011; Tockner et al. 2008). Exploitation and protection of alluvial aquifers are two objectives of the sustainable management of groundwater resources that need to be addressed in a strictly coupled way (Aral and Taylor 2011).

The recharge to groundwater, intended as the quantity of water feeding the aquifer system, can be considered a valuable parameter in order to quantitatively estimate the safe yield and the intrinsic vulnerability of an aquifer at the same time (Foster 1998; Healy 2010; Misstear et al. 2009; Robins 1998). Indeed, a permeable hydrologic connection between the aquifer and the ground surface allows a high contribution to the aquifer from direct recharge but, at the same time, increases the intrinsic vulnerability of aquifers to surface sources of pollution (Vrba and Zaporozec 1994). Environmental tracers such as the stable isotopic ratios of oxygen $\left(\delta^{18} \mathrm{O}\right)$ and hydrogen $\left(\delta^{2} \mathrm{H}\right)$ are a valuable tool identify the sources of groundwater recharge by means of mixing calculations (e.g. de Vries and Simmers 2002; Gemitzi et al. 2014; Gibson et al. 2005; Liu et al. 2004; Liu and Yamanaka 2012; Mizota and Kusakabe 1994; Nakaya et al. 2007; Qin et al. 2011; Rietti-Shati et al. 2000; Weyhenmeyer et al. 2002; Wilcox et al. 2004) and thus to perform a physically based assessment of the intrinsic vulnerability. Such assessment of intrinsic vulnerability is based on the common hydrogeologic assumption that low permeability layers (i.e. aquitards) help protect the quality of groundwater hosted in the underlying aquifers. In recent years, however, contamination is often found in confined aquifers, and is attributed to preferential pathways such as open fractures, root holes, stratigraphic windows or unsealed boreholes (e.g. Chapuis 2013; Pedretti et al. 2013). "Aquitard integrity" refers to the capability of an aquitard to provide protection to an underlying aquifer (Cherry et al. 2006). Contamination of confined aquifers often involve dense non-aqueous phase liquids (DNAPLs; Parker et al. 2004). Due to their peculiar physico-chemical properties (i.e. denser and less viscous than water), DNAPLs are inclined to travel much faster through aquitards than dissolved contaminants, the last ones being strongly retarded due to sorption and mass transfer into the aquitard matrix by diffusion. Therefore, until strong evidence is obtained to the contrary, it is prudent to assume that DNAPLs can penetrate into or through most types of aquitards due to natural preferential pathways, even those with very low bulk hydraulic conductivity (Parker et al. 2004). Although deep penetration of DNAPL in fractured aquitards has been documented at several sites, intensive field studies also showed some aquitards as capable of preventing DNAPL penetration and others allowing partial but not full penetration (Morrison et al. 1998; Parker et al. 2004; Roberts et al. 1982; Schwartz et al. 1982). The existing literature concerning the migration of DNAPLs through low permeability layers is mainly focused on hard rock aquitards and very few studies exist that analyze the capability of unconsolidated aquitards to protect the underlying aquifers against DNAPLs (e.g. Parker et al. 2004; Pedretti et al. 2013). The most useful information in order to assess aquitard integrity against DNAPLs are usually internal data, such as hydraulic head measurements or water samples collected from piezometers screened inside the aquitard. External measurements, such as hydraulic heads in aquifers above and below an aquitard, provide only indirect evidences of the aquitard performances (Cherry et al. 2006; Pedretti et al. 2012).

Among the chemical species composing DNAPL mixtures, chlorinated solvents represent the most ubiquitous in groundwater (Stroo and Ward 2010). Their behavior in the subsurface, their potential to be subjected to biodegradation and the threats that can arise, depend largely on the intrinsic characteristics of the contaminants, but also on the geological and hydrogeological features of the system in which they migrate. These last features are particularly important in the case of unconsolidated porous settings constituted by layered sediments (e.g. alluvial plains), where the contaminants happen to have an intimated and pervasive contact with a very heterogeneous solid. In such a case, a detailed characterization of depositional facies is a valuable tool in order to identify and group together the geological and hydrogeological features of the system, possibly interacting with the contaminants (e.g. Bianchi and Pedretti 2017). For example, the occurrence in the stratigraphic architecture of organic-rich layers (such as peaty layers), could substantially affect the migration and degradation of contaminants, since the organic matter can sorb the contaminants and also act as electron donor in biodegradation reactions with potential production of hazardous metabolites (e.g. Vinyl Chloride; Stroo and Ward 2010).

This study is focused on a complex multilayered aquifer setting that corresponds to the southeastern sector of the Po Plain (Ferrara, northern Italy), where contamination by chlorinated solvents (mainly chlorinated ethenes) occurs at several sites. In some of these sites, a peculiar accumulation of Vinyl Chloride as a degradation product of higher chlorinated compounds was also osbserved in the confined aquifers, with the formation of Vinyl Chloride-only plumes (e.g. Pasini et al. 2008). A detailed investigation has been carried out in one contaminated test-site (the Caretti site) where industrial wastes from the production of chloromethanes were illegally stored in a local dump (known as the Southern Dump), five to six decades ago. The contamination at the Southern Dump is mostly composed by chlorinated ethenes, which originally migrated down through the multiaquifer system in the shape of DNAPLs. Several types of hydrogeologic data (i.e. stratigraphic data, hydraulic heads, hydrochemical composition of water, stable isotopes of water and contaminants) have been collected along a cross section disposed on a peripheral fringe of the Southern Dump by means of multilevel monitoring systems and other innovative sampling and analytical techniques, in order to achieve these aims: (1) to assess the intrinsic vulnerability of the multiaquifer system in a physically based way (i.e. by means of water stable isotopes), (2) to evaluate the integrity of the 
local aquitards against chlorinated solvent contaminants that entered the subsurface in the DNAPL phase, (3) to investigate the origin of Vinyl Chloride formation and accumulation that was observed the confined aquifers of the investigated setting.

\section{Methods Study site}

The eastern sector of the Po river plain (northern Italy) is a classic example of a system of multiple, stacked alluvial aquifers. The hydrostratigraphy consists of an alternation of fine to coarse grained sands of higher hydraulic conductivity (aquifers) with silty-clayey layers of lower hydraulic conductivity (aquitards), down to a depth of around $200 \mathrm{~m}$ b.g.s. (Molinari et al. 2007). The two main aquifers occurring in the shallower $60 \mathrm{~m}$ are known as A0 and A1 (Regione Emilia-Romagna and ENI-AGIP 1998). The aquitards are named after the underlying aquifers as Q0 and Q1, from the surface. The A0 aquifer is Holocenic and structured in paleo-river beds or in scattered lenses intermingled with finegrained overbank deposits; the deeper A1 aquifer is Upper
Pleistocenic deposited as a channel belt during glacial events (Amorosi and Colalongo 2005). A recent unpublished work in the study area has focused on the stratigraphic architecture of the Holocene succession, identifying a thick interval of transgressive swamp deposits (peats and organic-rich clays) in the Q0 and Q1 aquitards. The recharge of such a hydrogeologic system occurs at three levels: (1) vertical recharge from rainfall, (2) lateral recharge from the Po river, and (3) deep regional ground water flow from the distant borders of the Po plain, where macroclastic permeable deposits outcrop as alluvial fans (i.e., along the foothills of the Alps, $70 \mathrm{~km}$ north of Ferrara, and the foothills of Apennines, $40 \mathrm{~km}$ south).

The research is focused on one contaminated site, known as the Caretti site. This is a neighborhood extended for about $1 \mathrm{~km}^{2}$, located $1 \mathrm{~km}$ eastward from the historical center of Ferrara (Fig. 1). At the Caretti site, the A1 aquifer consists of two distinct, locally amalgamated sand bodies (lower A1 and upper A1 aquifers, overlain by lower Q1 and upper Q1 aquitards, respectively) (Fig. 2). Additional information about the regional and local flow system is reported by Nijenhuis et al. (2013) and Filippini et al. (2016).
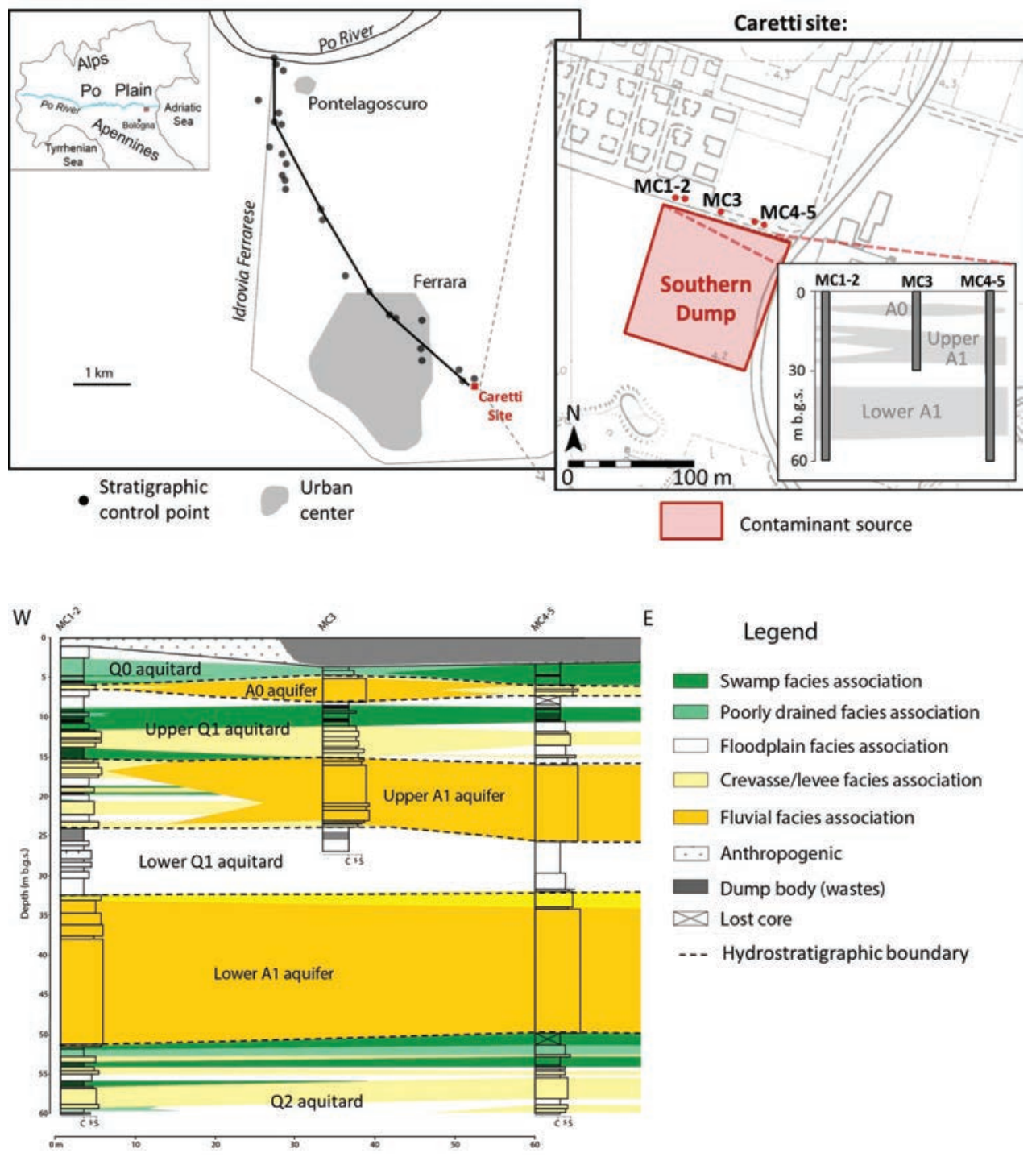

Fig. 1 - Location of the study area. The left box shows the points used for stratigraphic reconstruction across the Ferrara region. Details about the Caretti site (configuration of the monitoring cross-section in relation with the source of contamination) are sketched on the right.

Fig. 1 - Collocazione dell'area di studio. Il riquadro a sinistra mostra i punti utilizzati per le ricostruzioni stratigrafiche nell'area di Ferrara. Nel riquadro a destra sono schematizzati alcuni dettagli riguardo al sito Caretti (configurazione del transetto di monitoraggio in relazione alla sorgente di contaminazione).
Fig. 2 - Depositional facies architecture along the monitoring cross-section (Caretti site). The black dashed lines demarcate different bydrostratigraphic bodies (i.e. aquifers and aquitards).

Fig. 2 - Architettura delle facies deposizionali lungo il transetto di monitoraggio al sito Caretti. Le linee nere tratteggiate evidenziano le interfacce tra acquiferi ed acquitardi. 


\section{The issue of chlorinated solvents in Ferrara}

The aquifers below Ferrara are burdened by a groundwater contamination peculiar in terms of severity and chemical composition. Chlorinated solvents with concentrations up to $1 \times 10^{4} \mu \mathrm{g} / \mathrm{L}$ occur below industrial, residential or agricultural areas. Vinyl Chloride (VC) dominates the composition of the contaminant plumes (Gargini et al. 2011). The origin of the plumes is related to local sources directly or indirectly linked with industrial activities (Nijenhuis et al. 2013). Highly chlorinated compounds were spilled in the environment as industrial wastes, while VC must represent a product of dechlorination of former compounds. The high VC concentrations suggest strong propensity for perchloroethilene (PCE), trichloroethylene (TCE) and cis-Dichloroethilene (cDCE) to degrade. Differently, the degradation of VC to ethene appears slower with respect to the highly chlorinated compounds. The common occurrence of VC accumulation and persistence within the region suggests strong association with the local geologic, hydrogeologic and geochemical setting (Filippini et al. 2016). Focusing on the Caretti site, previous investigations revealed that the aquifers $A 0$ and Upper $A 1$ are strongly contaminated by chlorinated hyrdrocarbons (Gargini et al. 2011). The contamination originates from urban wastes and chlorinated pitches containing a mixture of chloroethenes and chloroethanes in the DNAPL phase, which were disposed in a clay pit (known as Southern Dump) in the late 1950s and 1970s. Two plumes of dissolved contaminants were identified in the A0 and Upper A1 aquifers that migrated up to $500 \mathrm{~m}$ from the Southern Dump. The plumes are mainly composed by chlorinated ethenes. VC dominates on the other chloroethene compounds downgradient to the contaminant source.

In the Ferrara region, the confined A1 aquifer is exploited at several locations for irrigation or drinking water purposes and the overlying confining aquitard is considered to be capable to protect the quality of aquifer groundwater in several technical documents.

\section{Stratigraphic reconstruction and facies analysis}

In order to reconstruct a reliable stratigraphic framework for the study area, the whole stratigraphic database hosted at the Emilia-Romagna Geological Survey (RER) was considered (see control points in Fig. 1). Stratigraphic descriptions include color, lithology, accessory material and, in a few instances, pocket penetrometer values. During summer 2013, three cores were recovered from three boreholes named MC1-2, MC3 and MC4-5, disposed along a cross-section $60 \mathrm{~m}$ long and $60 \mathrm{~m}$ thick at the Caretti site (Fig. 1, 2). Very detailed stratigraphic description was performed on these cores, down to the $\mathrm{cm}$ scale. Pocket penetrometer tests were performed in the field on clayey layers. Facies interpretation from the three cores (Fig. 2) was used for calibration of stratigraphic data extracted from the RER dataset. As a result, each stratigraphic description was tentatively converted into facies data. Facies analysis was used as a basis for stratigraphic correlations, allowing reconstruction of facies architecture at regional scale (Fig. 3).

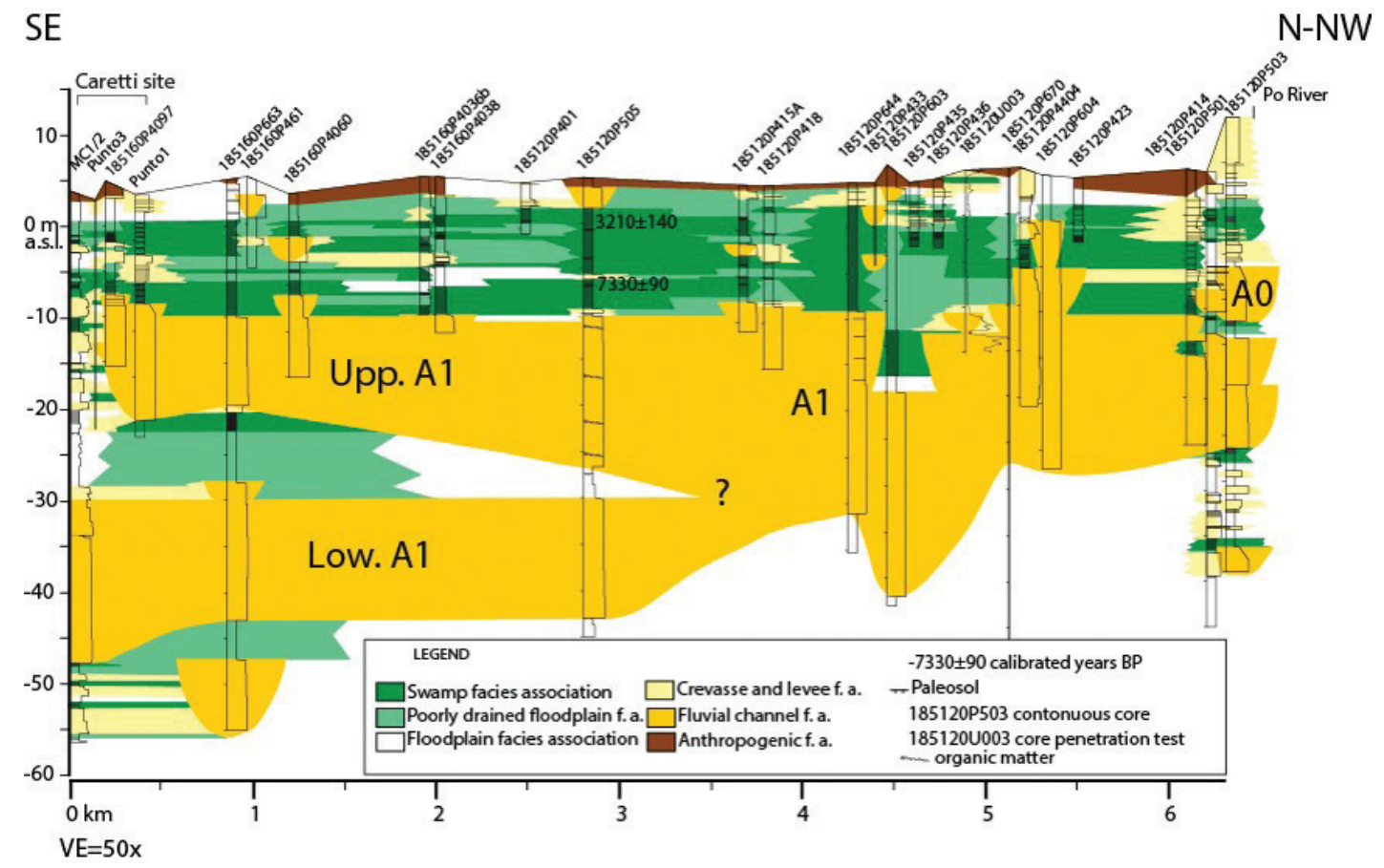

Fig. 3 - Depositional facies and hydrostratigraphic architecture in the Ferrara area. The locations of the profiles used to realize the transect are indicated in Fig. 1. (Reprinted from Filippini et al., 2016, with permission from Elsevier).

Fig. 3 - Architettura delle facies deposizionali ed idrostratigrafia nell'area di Ferrara. La posizione dei sondaggi utilizzati per costruire il profilo è mostrata in Fig. 1. (Ristampata da Filippini et al., 2016, con autorizzazione di Elsevier). 


\section{Cross-section and Multilevel systems}

The main sampling network used in this research corresponds to the cross-section at the Caretti site, already mentioned in Section 2.3. The cross-section is located on the northern fringe of the Southern Dump (i.e. the main source of contamination at the site) and consists of three vertical profiles 30 to $60 \mathrm{~m}$ deep, spaced 21 to $25 \mathrm{~m}$ apart from each other. The two deeper profiles (MC1-2 and MC4-5 in Fig. 1) consist of two coupled boreholes spaced apart 4 to $5 \mathrm{~m}$. The shallower portions ( 0 to around $30 \mathrm{~m}$ b.g.s.) of MC2 and MC5 boreholes were sealed with permanent casing before advancing the drilling to the bottom, in order to avoid crosscontamination of the deepest investigated aquifer (Lower A1), which was considered uncontaminated before this study, based on a site characterization performed by the local authorities. Five multilevel monitoring systems (Solinst ${ }^{\circledR}$ CMT System) (Einarson and Cherry, 2002) were installed in the boreholes along the cross-section. Each of the five CMTs is equipped with 7 screens at discrete depths, both in aquifers and aquitards. Several groundwater and sediment samples were collected along the cross-section both from aquifer and aquitard layers.

\section{Sediment and groundwater Sampling}

Different types of sediment core sub-samples were collected along the three profiles of the cross-section.

Samples $0.1-0.2 \mathrm{~m}$ long were taken every $2.5 \mathrm{~m}$ in the aquifers and every $0.5 \mathrm{~m}$ in the aquitards along the MC12 profile to analyze $\delta^{18} \mathrm{O}$ on the pore water. The sampling method followed Hendry and Wassenaar (2009), Stumpp and Hendry (2012) and Wassenaar et al. (2008). Samples were double bagged in polyethylene and refrigerated.

Bigger sediment samples (around $250 \mathrm{~g}$ each) were collected at 1-meter resolution from profiles MC1-2 and MC3 to analyze the grain size distribution of the sandy and the silty clay-rich layers.

Cores collected along the MC4-5 profile were sub-sampled in July 2013 for the determination of physico-chemical properties of sediments and for quantitative laboratory analysis of VOCs and their respective compound specific isotope composition $\left(\delta^{13} \mathrm{C}\right)$. The subsampling procedure is described in detail by Adamson et al. (2015), Parker et al. (2004) and Parker et al. (2003). Five subsamples were collected at each depth, one to determine sediment properties (estimated total porosity and organic carbon fraction, $\mathrm{f}_{\mathrm{oc}}$ ), one dedicated to contaminant concentration analysis and three dedicated to the Compound Specific Isotope Analysis (CSIA). The samples for sediment properties were collected in preweighed $20 \mathrm{~mL}$ scintillation vials. The samples for contaminant concentration were extruded into a pre-weighed $25 \mathrm{~mL}$ glass VOA (volatile organic analysis) bottle, containing a known volume of HPLC-grade methanol (around $15 \mathrm{~mL}$ ) for preservation and contaminant extraction. Samples for isotopic analyses were extruded into $20 \mathrm{~mL}$ headspace (HS) crimp vials, containing $9.5 \mathrm{~mL}$ of $\mathrm{NaCl}$ water saturated solution (for preservation and salting out of the contaminants). All the samples were stored at $2^{\circ} \mathrm{C}$ to $4^{\circ} \mathrm{C}$ prior to the shipment to the laboratory.

Groundwater samples were collected from the CMTs in November 2013 to analyze $\delta^{18} \mathrm{O}$ and $\delta^{2} \mathrm{H}$, hydrochemistry, contaminant concentration and dissolved gas concentration (i.e. ethene, methane).

Groundwater samples were collected after stabilization of physico-chemical parameters monitored via a flowcell equipped with electrodes for the determination of temperature, specific electric conductivity, $\mathrm{pH}$ and Eh (QuantaD, Hydrolab®). For $\delta^{18} \mathrm{O}$ and $\delta^{2} \mathrm{H}$ measurement, $100 \mathrm{~mL}$ of each sample was stored unfiltered in a PET bottle. Samples for hydrochemical analyses were pre-filtered at 45 $\mu \mathrm{m}$ in the field and filled into two $250 \mathrm{~mL}$ PET bottles: one was not acidified (for anions) and the second one was acidified to $\mathrm{pH} \leq 2$ with nitric acid (for cations). Samples dedicated to contaminant concentration analyses were collected in 1 L Schott glass bottles sealed with Teflon ${ }^{\mathrm{TM}}$ lined screw caps. For concentration analysis of dissolved gases, $220 \mathrm{~mL}$ serum bottles were filled to the top, acidified immediately (hydrochloric acid to $\mathrm{pH}$ 2) and closed with butyl rubber stoppers capped with aluminum crimp seals. All the samples were stored at $4{ }^{\circ} \mathrm{C}$ until analysis.

\section{Analytical methods Sediments}

Organic Carbon content $\left(f_{o c}\right)$ on core subsamples was determined via both Combustion/NDIR and Walkley-Black methods (Nelson and Sommers 1996).

$\delta^{18} \mathrm{O}$ on sediment samples were measured using $\mathrm{H}_{2} \mathrm{O}$ (liquid) $-\mathrm{H}_{2} \mathrm{O}$ (vapor) pore water equilibration and off-axis laser spectroscopy (Wassenaar et al. 2008). This method allows $\delta^{18} \mathrm{O}$ to be measured directly in soil cores with volumetric water contents $>5 \%$, with an accuracy of $<2 \%$. $\delta^{18} \mathrm{O}$ obtained by means of sediment core sampling will be indicated as "pore water" in the following sections to differentiate them from the results obtained by the conventional groundwater samples (respectively referred to as "groundwater").

Sediment subsamples dedicated to chlorinated ethene concentration (PCE, TCE, cDCE, VC) were analyzed at the Parker research lab at the University of Guelph, following the technique described by Parker et al. (2003). This analytical technique provides the total analyte content per mass of wet sediment, and therefore does not distinguish between concentrations present in the aqueous, sorbed and/or NAPL phases. Calculations were used to distinguish the three phases, modified from Feenstra et al. (1991) in the same manner as Parker et al. (2003).

Gas chromatography combustion isotope ratio mass spectroscopy (GC-C-IRM-MS) was applied to determine the stable carbon isotope composition of the volatile organic contaminants (i.e. chlorinated ethenes) in the sediment samples, as described by Filippini et al. (2016).

\section{Groundwater}

The stable isotope ratios $\left(\delta^{18} \mathrm{O}\right.$ and $\left.\delta^{2} \mathrm{H}\right)$ on groundwater samples were measured at the Department of Isotope 
Biogeochemistry, at the Helmholtz Centre for Environmental Research in Leipzig (Germany) by isotope ratio mass spectrometry, using an elemental analyzer (EA1108, CE Instruments, Italy) equipped with a high temperature furnace (Hekatech, Wegberg, Germany) and coupled to a Finnigan MAT 253 Stable Isotope Ratio Mass Spectrometer (Thermo Fisher Scientific, Bremen, Germany).

Groundwater samples collected for major ions were analyzed by Ion chromatography for anionic species using a Metrohm 883 Basic IC Plus chromatographer. Major cations were analyzed by Flame Atomic Absorption Spectrometry with a Perkin Elmer AA100 spectrometer.

VOC concentrations in groundwater were analyzed by a private certified laboratory, using the analytical methods "EPA 5030 C" and "EPA 8260 C".

Ethene and methane concentrations were analyzed on groundwater samples at the Department of Isotope Biogeochemistry, at the Helmholtz Centre for Environmental Research in Leipzig (Germany) using gas chromatography with flame ionization detection (GC-FID).

\section{End-Member Mixing Analysis}

End-Member Mixing Analysis (EMMA) was applied to the isotopic compositions of the groundwater samples to identify and quantify the water sources contributing to the recharge of the different aquifers. This technique assumes the following (Barthold et al. 2011): (1) groundwater is a mixture of source substances with a fixed composition; (2) the mixing process is linear and completely dependent on hydrodynamic mixing; (3) the substances used as tracers are conservative; and (4) the source substances have extreme concentrations. Eq. (1), proposed by Clark and Fritz (1997), was applied to each point, starting from both $\delta^{18} \mathrm{O}$ and $\delta^{2} \mathrm{H}$ values:

$$
\delta_{\mathrm{s}}=\mathrm{X} * \delta_{\mathrm{A}}+(1-\mathrm{X}) * \delta_{\mathrm{B}}
$$

where $\delta$ represents the isotopic ratio relative to oxygen or hydrogen, $\mathrm{S}$ stands for the sample, $\mathrm{A}$ and $\mathrm{B}$ are the two considered end-members and $\mathrm{X}$ is the fraction of end-member $A$ in the binary mixture. The two End Members considered in this research are the average isotopic composition of local rainfall and one of the Po river (determined as described by Filippini et al. 2015). The intensity of the signal of vertical recharge quantified by EMMA was used as a proxy of the intrinsic vulnerability of aquifers against surface sources of contamination, considering contributions of $100 \%$ and $0 \%$ from vertical recharge as the highest and lowest possible degree of vulnerability, respectively.

\section{Results}

\section{Depositional facies}

Detailed sedimentological analyses of cores collected at the Caretti site (MC1-2, MC3 and MC4-5) enabled the identification of five facies associations (Fig. 2) on the basis of sediment lithology, stratigraphic boundaries, grain size trends, sediment color, thickness, and accessory materials (e.g., fossil content, organic matter, plant debris). Additional data include in situ pocket penetrometer tests from core MC1-2. The facies associations that have been identified along the cross section are: the fluvial-channel facies association, the levee and crevasse facies association, the floodplain facies association, the poorly-drained floodplain facies association, the swamp facies association. This last facies association is particularly important for the present research (as discussed in Section 4.3) and is made up of dark grey to black organic-rich clay, with abundant mm-sized plant debris and leaf fragments. The black and dark grey colors indicate an abundance of organic matter. A characteristic peat horizon, about $1 \mathrm{~m}$ thick, forms a prominent marker bed in the basal portion of this facies association. The dark clay is commonly very soft, as revealed by its very low pocket penetrometer values ( 0.2 to 1.2 $\left.\mathrm{kg} / \mathrm{cm}^{2}\right)$. Details on the other facies associations are reported by Filippini et al. (2016).

\section{Water stable isotopes}

The vertical isotope pattern obtained from groundwater samples at the Caretti site shows general consistence with the averaged compositions determined in the same aquifers at the regional scale (described by Filippini et al. 2015) (Fig. 4).

The vertical isotope distribution obtained by pore water analysis is consistent with that from groundwater. Two main differences were identified between the two sets of data (compared in Fig. 4a). First, pore water samples show a sharp and well-defined composition gradient within the Upper Q1 and Lower Q1 aquitards; the gradients are less pronounced in the groundwater samples within the aquitards. Second, more systematic enriched $\delta^{18} \mathrm{O}$ ratios can be observed in the pore water compared with the groundwater (averaged $\Delta=0.4 \%$ ). These two differences may be related to the different resolution of sampling used for the two sampling methods (i.e., groundwater and pore water), or to other reasons, such as sampling of different water fractions or peculiarities of the analytical methods.

The aquifer recharge (as a proxy for intrinsic vulnerability) was quantified starting from the groundwater results and gives different source ratios for the investigated aquifers (Fig. 4b).

\section{Contaminant distribution}

The total concentration of VOCs $\left(C_{t} \mu g / g\right.$ wet sediment) was determined from sediment subsamples at $0.1 \mathrm{~m}$ scale resolution along the MC4-5 profile. The main chloroethenes occurring along the profile were labeled as parent compounds (i.e. PCE and TCE, spilled at the source) or daughter compounds (i.e. cDCE and VC, produced by biodegradation). Each compound has a very heterogeneous vertical distribution, with changes in concentration up to 2 order of magnitude at the $0.1 \mathrm{~m}$ scale (Fig. 5). PCE and TCE occur along the whole profile, with the highest concentrations located in the A0 aquifer (in direct contact with the source of contamination) and at the top of the Upper Q1 and Lower Q1 aquitards. VC and cDCE occur almost exclusively in the Q0 aquitard (3 to $5.5 \mathrm{~m}$ b.g.s.) and in the shallow part of the Upper Q1 aquitard (8 to $11 \mathrm{~m}$ b.g.s.), while they are almost absent in the deeper sections of the profile. 


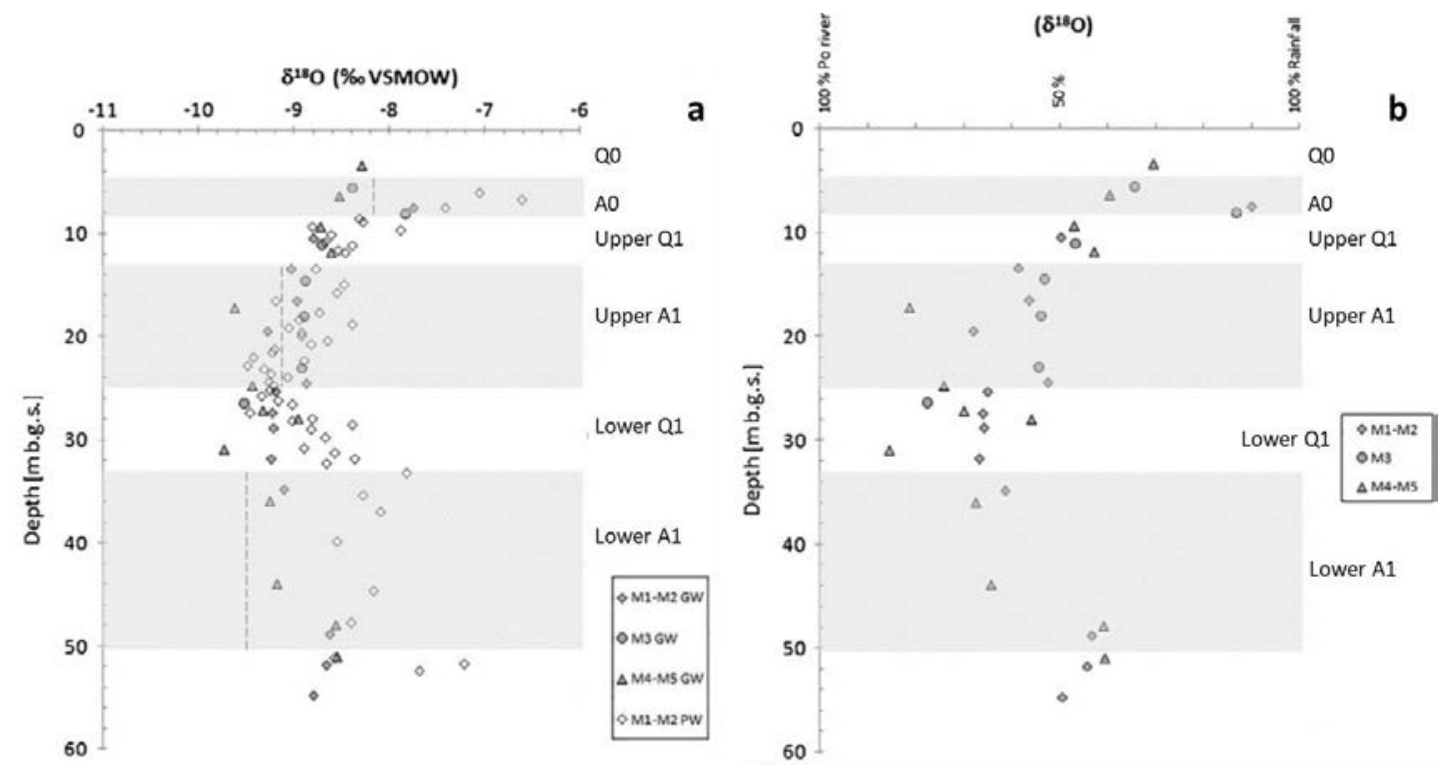

Fig. 4 - (a) vertical distribution of the isotopic composition $\left(\delta^{18} O\right)$ of groundwater $(G W)$ and pore water $(P W)$, along the three profiles of the cross-section. The dashed lines represent the averaged isotopic composition of the different aquifers at the regional scale (Filippini et al., 2015); (b) Vertical distribution of the percentages of recharge obtained from $\delta^{18} O \mathrm{O}$ along the three profiles of the cross-section. (Reprinted from Filippini et al. 2015, with permission from Elsevier).

Fig. 4 - (a) distribuzione verticale della composizione isotopica $\left(\delta^{18} \mathrm{O}\right)$ dell'acqua sotterranea $(\mathrm{GW})$ e dell'acqua interstiziale (PW) lungo i tre profili del transetto di monitoraggio. Le linee tratteggiate rappresentano la composizione isotopica media dei differenti acquiferi alla scala regionale (Filippini et al., 2015); (b) distribuzione verticale delle percentuali di ricarica ottenute tramite $\delta^{18} \mathrm{O}$ lungo i tre profili del transetto (ristampata da Filippini et al. 2015, con autorizzazione di Elsevier)."

The dissolved $\left(\mathrm{C}_{\mathrm{w}}\right)$ and sorbed $\left(\mathrm{C}_{\mathrm{s}}\right)$ concentrations of chloroethenes were estimated from the total concentration in wet sediment $\left(C_{t}\right)$ (Fig. 5,6 ). Sorbed contaminants $\left(C_{s}\right)$ are mostly PCE and TCE, with the highest concentrations (203 and $96 \mu \mathrm{g} / \mathrm{g}$, respectively) at the top of the Upper Q1 aquitard, within the organic rich layers located between 8 and $11 \mathrm{~m}$ b.g.s. $C_{\mathrm{w}}$ distribution shows the highest peaks of dissolved contaminants in the A0 aquifer, in the Q0 and in the Upper Q1 aquitards. The cDCE and VC prevail as dissolved compounds in the fine-grained layers (Q0 and Upper Q1 aquitards), with concentrations up to 168 and $49 \mathrm{mg} / \mathrm{L}$, respectively. Dissolved PCE and TCE prevail in the A0 (max concentrations equal to 133 and $73 \mathrm{mg} / \mathrm{L}$, respectively), showing also a secondary peak at the top of the Lower Q1 aquitard (concentrations equal to 45 and $12 \mathrm{mg} / \mathrm{L}$, respectively).

The occurrence of pure phase DNAPL was excluded in the sediment samples by comparing the estimated dissolved concentration $\left(\mathrm{C}_{\mathrm{w}}\right)$ with the solubility of compounds.

Concentrations measured from groundwater samples ("GW") are generally lower than $\mathrm{C}_{\mathrm{w}}$ (Fig. 6). The higher $\mathrm{C}_{\mathrm{w}}$ values with respect to the GW can be justified as follows: (1) groundwater samples only represent porewater of higher permeability layers whereas the sediment sampling also includes contaminant mass stored in the porewater of the lower $\mathrm{K}$ zones, (2) results from sediment samples are representative of point concentrations whereas the GW represent the mean concentrations along a 0.2 to $2 \mathrm{~m}$ thickness (i.e. the thicknesses of gravel packs around the CMT screens).

GW samples were collected also along the MC1-2 and MC3 profiles (Fig. 6). The results show that the contamination is absent in the shallower section of $\mathrm{MC1}-2$ (Q0 and $\mathrm{A0}$ ), occurring in significant concentrations only in the Upper A1 aquifer. This is due to the absence of residual wastes above the western profile (see Fig. 2).

\section{Redox conditions}

Markedly negative values of Eh were detected in groundwater along the whole cross-section (range from -278 to $-160 \mathrm{mV}$ ) and dissolved oxygen was invariably measured at concentration lower than $0.4 \mathrm{mg} / \mathrm{L}$ (results from profile MC4-5). Methane was found in all groundwater samples at concentrations above $31 \mathrm{mg} / \mathrm{L}$. These confirm overall occurrence of anoxic condition along the investigated system.

\section{Compound Specific Isotope Analysis}

The general depleted $\delta^{13} \mathrm{C}$ values obtained for chlorinated ethenes in the study area $\left(-76 \% 0<\delta^{13} \mathrm{C}<-51 \%\right.$; Fig. 7$)$, in comparison to those values expected for common chlorinated solvents $\left(-37 \% 0<\delta^{13} \mathrm{C}<-23 \%\right.$ ) (Hunkeler et al. 2005; Sherwood Lollar et al. 2000; Shouakar-Stash et al. 2003), are related to the characteristics of the primary source of contamination, described by Nijenhuis et al. (2013). The $\delta^{13} \mathrm{C}$ was analyzed on sediment samples corresponding to the main peaks of contaminant concentration along the MC4-5 profile, where peak concentrations of daughter compounds occur into the swamp facies and peak concentrations of parents occur into facies other than swamp. $\delta^{13} \mathrm{C}$ of samples collected in 


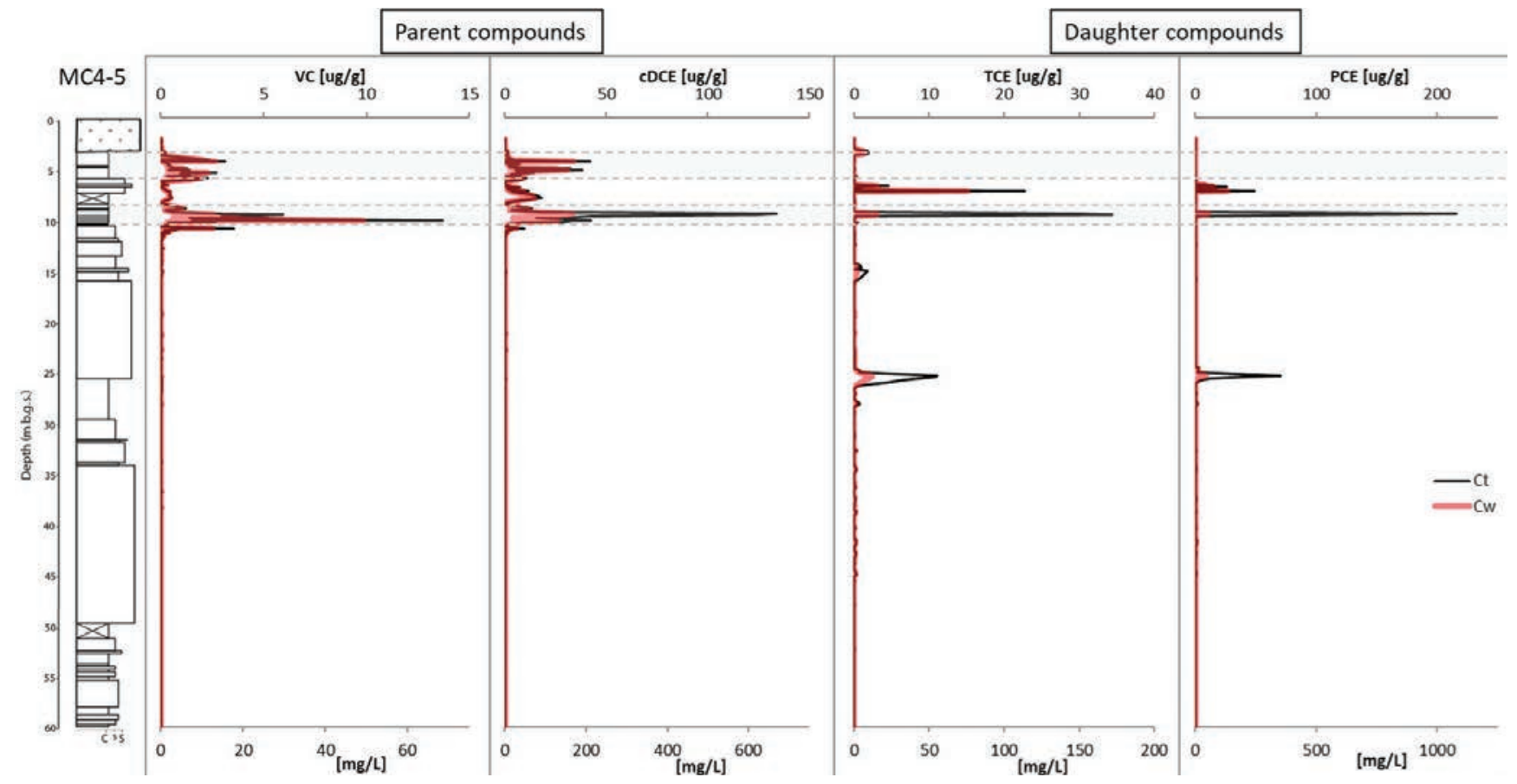

Fig. 5 - Vertical distribution of chlorinated ethenes obtained by core subsamples and groundwater samples collected along profile MC4-5. The total concentrations of the main analytes $\left(C_{t} ; u g / g\right.$ wet soil) are reported together with estimated dissolved concentrations $\left(C_{w} ; \mathrm{mg} / L\right)$. Dissolved concentrations obtained by groundwater samples are referred to as $G W$, and expressed in $\mathrm{mg} / \mathrm{L}$. The location of swamp deposits is highlighted in light grey.

Fig. 5 - Distribuzione verticale delle concentrazioni di eteni clorurati ottenute tramite campioni di sedimento e di acqua sotterranea lungo il profilo MC4-5. Le concentrazioni totali degli analiti $\left(\mathrm{C}_{\mathrm{t}} ; \mathrm{ug} / \mathrm{g}\right)$ sono riportate insieme alle concentrazioni disciolte stimate a partire dalle concentrazioni totali $\left(\mathrm{C}_{\mathrm{w}} ; \mathrm{mg} / \mathrm{L}\right)$. Le concentrazioni disciolte ottenute tramite l'analisi dei campioni di acqua sotterranea sono indicate con $\mathrm{GW}(\mathrm{mg} / \mathrm{L})$. La posizione dei depositi di palude è evidenziata in grigio.

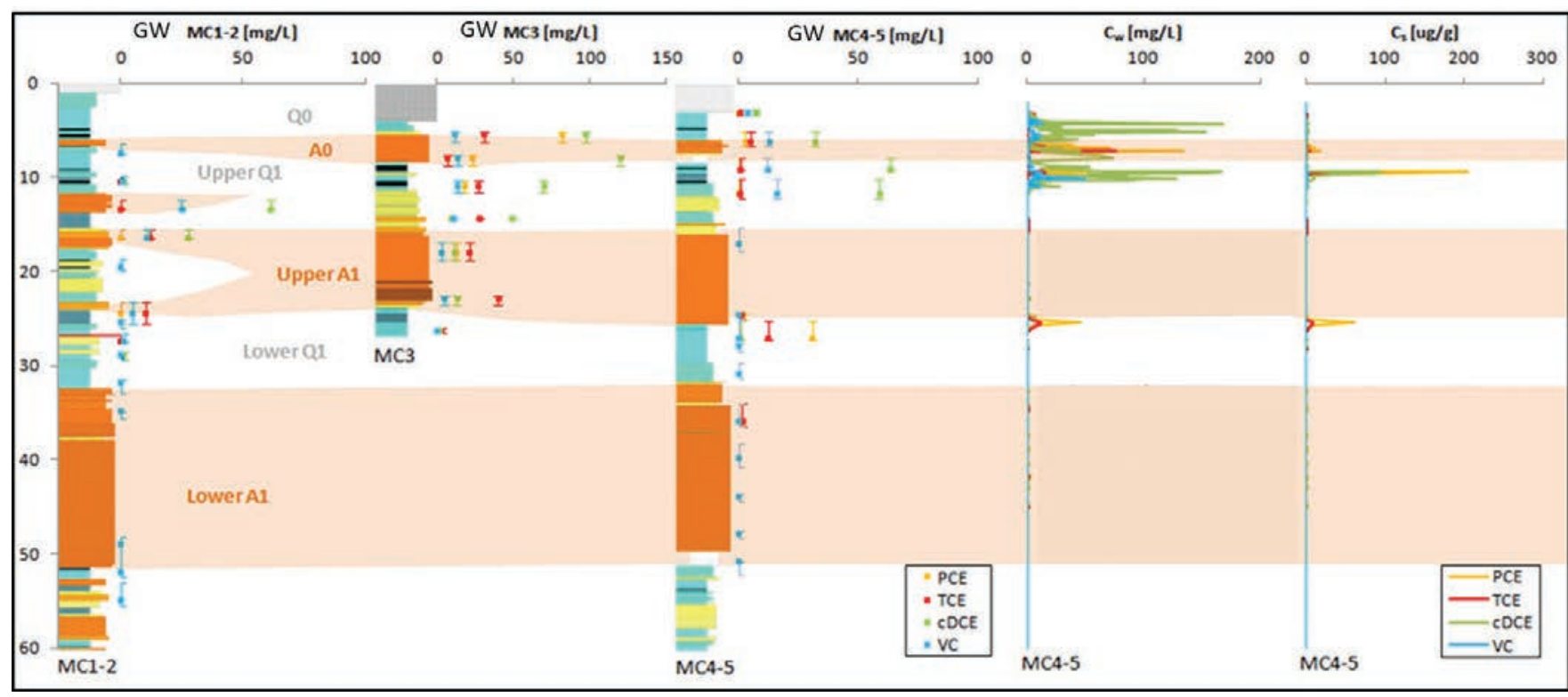

Fig. 6 - Vertical distribution of chloroethenes in dissolved and sorbed phases. From the left are shown: the distribution of dissolved concentrations obtained by groundwater samples collected from all the CMT systems $(G W ; \mathrm{mg} / \mathrm{L})$; the estimated dissolved $\left(C_{w} ; \mathrm{mg} / \mathrm{L}\right)$ and sorbed $\left(C_{s} ; \mu \mathrm{g} / \mathrm{g}\right)$ concentrations obtained by phase partitioning calculations along profile MC4-5.

Fig. 6 - Distribuzione verticale degli eteni clorurati nella fase disciolta ed adsorbita. Da sinistra: concentrazioni di eteni clorurati ottenute da campioni di acqua sotterranea raccolti lungo $\mathrm{i}$ tre profili del transetto di monitoraggio $(\mathrm{GW} ; \mathrm{mg} / \mathrm{L})$; concentrazioni disciolte $\left(\mathrm{C}_{\mathrm{w}} ; \mathrm{mg} / \mathrm{L}\right)$ ed adsorbite $\left(\mathrm{C}_{\mathrm{s}}\right.$; ug/g) stimate a partire dalle concentrazioni totali nei campioni di sedimento lungo il profilo MC4-5. 
swamp deposits (i.e. peaks of concentration of daughter compounds) are clearly differentiated from the ones collected in other facies associations (i.e. peaks of concentration of parent compounds). In the case of the swamp facies, parent compounds show $-56 \% 0<\delta^{13} \mathrm{C}<-50 \%$ and daughter compounds show $-76 \% 0<\delta^{13} \mathrm{C}<-61 \%$. In the case of other facies, parent compounds show $-75 \%$ and $-68 \%$ (similar to daughters in swamps), and no (or very low concentration) daughter compounds were detected.

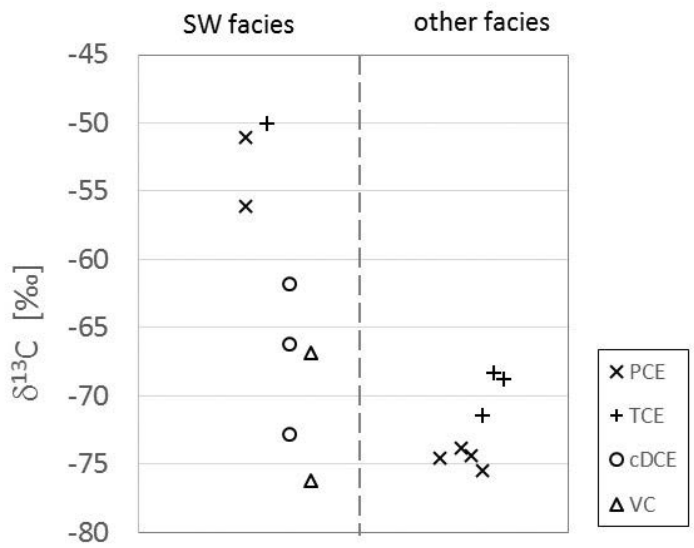

Fig. $7-\delta^{13} C$ of chlorinated ethenes from sediment subsamples collected along profile $M C 4-5$. Samples collected in the swamp facies association $(S W)$ are separated from the ones collected in other facies associations. (Reprinted from Filippini et al. 2016, with permission from Elsevier).

Fig. $7-\delta^{13} \mathrm{C}$ degli eteni clorurati da campioni di sedimento raccolti lungo il profilo MC4-5. I campioni raccolti entro la facies di palude (SW) sono separati da quelli raccolti in altre facies deposizionali (ristampata da Filippini et al. 2016, con autorizzazione di Elsevier).

\section{Discussion}

\section{Recharge quantification and intrinsic vulnerability}

The recharge trends obtained along the three vertical profiles of the transect (Fig. 4b) allow a detailed interpretation of the intrinsic vulnerability in the aquifers compared to the regional scale. The results at the regional scale are discussed by Filippini et al. (2015). Concerning the Caretti cross-section, the three aquifers show a degree of intrinsic vulnerability that decreases with depth. The highest vulnerability is the one of the A0 aquifer (up to $90 \%$ of recharge from rainfall) and the lowest is the one of the Lower A1 aquifer (down to $10 \%$ of recharge from rainfall at the top of the aquifer). More specifically, the higher percentages of vertical recharge at the top of the Upper A1 compared to the bottom ( $\mathrm{D}=7.93 \%$; Fig. 7 ) indicate that the groundwater in this aquifer is not completely mixed, and its upper part is influenced by recharge from A0 through the Upper Q1 aquitard. Concerning the Lower A1 aquifer, the isotopic gradient in the overlying aquitard Lower Q1, which is clearly visible from the pore water results (Fig. 4a), indicate diffusion controlled flow conditions (Hendry and Wassenaar, 2009), evidently excluding a direct connection between the Lower A1 and the shallower part of the system. Furthermore, a clear vertical trend can be identified in the aquifer (Fig. 4b): at the top the percentages obtained from $\delta^{18} \mathrm{O}$ suggest a main recharge contribution from the Po river, whereas an increasing influence from sources with enriched isotopic ratios can be observed at greater depths. This trend suggest the occurrence of a recharge supply from a third endmember in the lower section of Lower A1 (likely corresponding to the Apennine alluvial fans; Filippini et al 2015).

\section{Aquitard integrity against DNAPL}

Neither of the Upper Q1 and the Lower Q1 aquitards provide an adequate degree of protection to underlying aquifers against chlorinated solvent DNAPLs. Even though DNAPL occurrence was excluded at the time of sampling, the style of distribution of contaminants indicate the occurrence of DNAPL along the cross-section, or at least in the vicinity of it, in the past decades.

Both the Upper Q1 and Lower Q1 aquitards affected the vertical distribution of chloroethenes concentration and their transformation, in different ways that are related to their different stratigraphic features. Concerning the Upper Q1, the organic rich sublayers provide a favorable environment for reductive dechlorination (see Section 4.3) and contaminant sorption. Differently, no dechlorination occurs in the Lower Q1 aquitard. The evidence of contamination spread down to the Lower A1 aquifer (PCE and TCE in concentrations up to 3 $\mathrm{mg} / \mathrm{L}$ ) clearly indicates that preferential contaminant pathways (likely in DNAPL phase) must occur in the aquitard. Based on the site history, man-made interventions which could have caused cross-contamination of the Lower A1 aquifer can be excluded with good confidence. The occurrence of micro-fractures in the aquitard represent a likely preferential pathway for the migration of DNAPLs thought the protective clayey layer of the Lower Q1 aquitard. In the context of the southeastern Po river plain, a high consolidation of clays with consequent microfracturing can be attributed to clay desiccation occurred during the prolonged phase of subaerial exposure that characterized the area during the last glacial maximum and the first stages of transgression (Amorosi and Marchi 1999; Rizzini 1974). The same preferential pathways inferred for the migration of DNAPLs through the Lower Q1 aquitard are unlikely effective for the vertical migration of dissolved contaminants.

\section{Contaminant degradation and VC accumulation}

Comparison between theMC4-5 facies associations and the distribution of contaminants from sediment samples $\left(C_{w}\right.$; Fig. 6) clearly shows that peak concentrations of daughter compounds occur within the deposits classified as swamp facies association. This suggests that degradation of parent compounds (likely via reductive dechlorination; Bradley and Chapelle 2010; Nijenhuis and Kuntze 2016; Vogel et al. 1987) occurs inside these layers. Concentrations from groundwater samples along the same profile (GW, Fig. 6) corroborate occurrence of high degradation activity in the shallow section of MC4-5 (i.e. the shallowest $11 \mathrm{~m}$ b.g.s. were the swamp deposits occur). VC occurs in all shallow groundwater samples in concentrations ranging between 
0.5 and $3.5 \mathrm{mmol} / \mathrm{L}$, suggesting that dechlorination from VC to Ethene is significantly slower with respect to dechlorination of high chlorinated compounds (e.g. Cupples et al. 2004). Markedly negative Eh (likely over-depressed by the contamination itself), low dissolved oxygen values and high methane concentration in groundwater samples suggest the occurrence of methanogenic conditions along the whole system. This geochemical condition is the most favorable for reductive dechlorination (Stroo and Ward 2010) and was previously observed at the same field site (Nijenhuis et al. 2013). $\delta^{13} \mathrm{C}$ of parent compounds into the swamp facies is relatively enriched with respect to other sections of the profile, whereas in the SW facies daughters show $\delta^{13} \mathrm{C}$ as depleted as parents of other facies (Fig. 7). Assuming that PCE and TCE in sections other than swamps preserved the isotopic signature of the source (since no degradation products were detected in these samples), the $\delta^{13} \mathrm{C}$ pattern observed in the swamp layers would suggest fractionation due to complete dechlorination according to e.g. Bloom et al. (2000), Hunkeler et al. (2005), Slater et al. (2001). In contrast, no or very low dechlorination can be inferred in the deeper section of the MC4-5 profile (i.e. upper A1 aquifer and lower Q1 aquitard) based on contaminant concentration and isotopic evidences. The chloroethene degradation into the swamp facies observed at the Caretti site, explains the peculiar VC accumulations observed in several other contaminated sites in Ferrara, where the same stratigraphic and redox conditions subsist (Fig. 3) (details on the other contaminated sites are presented by Filippini et al. 2016).

\section{Conclusions}

A test-site located in an alluvial plain and strongly contaminated by chlorinated solvents was investigated in detail throughout this research, in order to assess the intrinsic vulnerability of aquifers and the integrity of aquitards against DNAPL contamination, and to identify the dynamics of contaminant degradation.

The stable isotopic signature of water was employed as a conservative natural tracer to quantify the relative amounts of recharge contributing to the different aquifers from the different local sources, by means of relatively simple mixing calculations. Considering the amount of vertical recharge (i.e. rainfall) as a proxy of the degree of interconnection with a possible surface source of contamination, the intrinsic vulnerability of the distinct aquifers was also evaluated. Moreover, strong isotopic gradients were detected inside the aquitards (pore water), thus confirming that the fine -grained layers behave as effective hydraulic barriers for the surrounding aquifers.

The pattern of migration of DNAPLs and associated dissolved chlorinated compounds was investigated in detail inside the multilayered aquifer-aquitard system. The vertical profiling of contaminants provided an evidence of the strong vertical migration capability of DNAPLs in respect to groundwater flow. Indeed, the local aquitards were easily crossed by DNAPLs and this caused the contamination of the deepest confined aquifer, which represents the main local fresh water reservoir for drinking and irrigation. The deep migration of contaminants observed at the site contradicts the intrinsic vulnerability assessment that suggested very low vulnerability for the deep aquifer.

Eventually, the mechanism of production and accumulation of vinyl chloride, observed in many of the contaminated sites in Ferrara, was investigated. A comparison between the depositional facies architecture and the vertical distribution of contaminants allowed inferring that the production of vinyl chloride is related with reductive dechlorination of higher chlorinated ethenes occurring within organic-rich swamp layers that occur at shallow depth in the local system. Compound Specific Isotope Analysis (CSIA) was performed on the contaminant molecules (the $\delta^{13} \mathrm{C}$ was determined on chlorinated ethenes) in order to verify the occurrence of reductive dechlorination down to VC.

The results achieved in the three investigation steps are useful not only for the obvious implications at the local scale (e.g. for the management of the contamination in the area of Ferrara), but also for the interpretation of contaminant migration and transformation in other alluvial plains contaminated by DNAPLs.

Acknowledgment: I acknowledge all the people that contributed to the presented research by providing resources and/or scientific support: Prof. Beth Parker (University of Guelph, Canada), Prof. Alessandro Gargini and Prof. Alessandro Amorosi (University of Bologna, Italy), Dr. Ivonne Nijenhuis and Dr. Hans Richnow (Helmholtz-Zentrum für Umweltforschung, Leipzig, Germany). I also acknowledge Dr. Daniele Pedretti and another anonymous reviewer for the useful comments and suggestions. 


\section{REFERENCES}

Adamson DT et al. (2015) Characterization and Source History Modeling Using Low-k Zone Profiles at Two Source Areas. Groundwater Monitoring \& Remediation: n/a-n/a.

Amorosi A, Colalongo ML (2005) The Linkage between Alluvial and Coeval Nearshore Marine Successions: Evidence from the Late Quaternary Record of the PO River Plain, Italy, Fluvial Sedimentology VII. Blackwell Publishing Ltd., pp. 255-275.

Amorosi A, Marchi N (1999) High-resolution sequence stratigraphy from piezocone tests: an example from the Late Quaternary deposits of the southeastern Po Plain. Sedimentary Geology, 128(1-2): 67-81.

Aral MM, Taylor SW (2011) Groundwater quantity and quality management. American Society of Civil Engineers, 592 pp.

Barthold FK et al. (2011) How many tracers do we need for end member mixing analysis (EMMA)? A sensitivity analysis. Water Resources Research, 47(8): W08519.

Bianchi M, Pedretti D (2017) Geological entropy and solute transport in heterogeneous porous media. Water Resources Research, 53(6): 4691-4708.

Bloom Y, Aravena R, Hunkeler D, Edwards E, Frape S, (2000) Carbon isotope fractionation during microbial dechlorination of trichloroethene, cis-1, 2-dichloroethene, and vinyl chloride: implications for assessment of natural attenuation. Environmental science \& technology, 34(13): 2768-2772.

Bradley PM, Chapelle FH (2010) Biodegradation of chlorinated ethenes, In situ remediation of chlorinated solvent plumes. Springer, pp. 39-67.

Chapuis RP (2013) Contamination of till aquitard by DNAPL : is it actual, or drilling artefact?. Geotechnical News, 31(4): 36-38.

Cherry JA et al. (2006) Contaminant Transport Through Aquitards: A "State of the Science" Review, AWWA Research Foundation, Denver, Colorado.

Clark I, Fritz P (1997) Environmental Isotopes in Hydrogeology. CRC Press, New York, 328 pp.

Cupples AM, Spormann AM, McCarty PL (2004) Vinyl Chloride and cis-Dichloroethene Dechlorination Kinetics and Microorganism Growth under Substrate Limiting Conditions. Environmental Science \& Technology, 38(4): 1102-1107.

de Vries JJ, Simmers I (2002) Groundwater recharge: an overview of processes and challenges. Hydrogeol. J., 10(1): 5-17.

Einarson MD, Cherry JA (2002) A New Multilevel Ground Water Monitoring System Using Multichannel Tubing. Ground Water Monitoring \& Remediation, 22(4): 52-65.

Feenstra S, Mackay DM, Cherry JA (1991) A Method for Assessing Residual NAPL Based on Organic Chemical Concentrations in Soil Samples. Ground Water Monitoring \& Remediation, 11(2): 128-136.

Filippini M et al. (2016) Origin of VC-only plumes from naturally enhanced dechlorination in a peat-rich hydrogeologic setting. Journal of Contaminant Hydrology, 192: 129-139.

Filippini M, Stumpp C, Nijenhuis I, Richnow HH, Gargini A (2015) Evaluation of aquifer recharge and vulnerability in an alluvial lowland using environmental tracers. Journal of Hydrology, 529, Part 3: $1657-1668$

Foster SSD (1998) Groundwater recharge and pollution vulnerability of British aquifers; a critical overview in: Groundwater pollution, aquifer recharge and vulnerability. Geological Society Special Publications, London, pp. 7-22.

Gargini A, Pasini M, Picone S, Rijnaarts H, Van Gaans P (2011) Chlorinated hydrocarbons plumes in a residential area. Site investigation to assess indoor vapor intrusion and human health risks. In: S. Saponaro, E. Sezenna and L. Bonomo (Editors), Vapor emission to outdoor air and enclosed spaces for human health risk assessment: site dharacterization, monitoring and modelling. Nova Science Publishers, Inc., Milan, Italy, pp. 211-233.
Gemitzi A, Stefanopoulos K, Schmidt M, Richnow HH (2014) Seawater intrusion into groundwater aquifer through a coastal lake complex interaction characterized by water isotopes ${ }^{2} \mathrm{H}$ and ${ }^{18} \mathrm{O}$. Isotopes in Environmental and Health Studies, 50(1): 74-87.

Gibson JJ et al. (2005) Progress in isotope tracer hydrology in Canada. Hydrol Process 19: 303-327.

Healy RW (2010) Estimating groundwater recharge. Cambridge University Press, Cambridge, UK.

Hendry MJ, Wassenaar LI (2009) Inferring heterogeneity in aquitards using high resolution $\delta \mathrm{D}$ and $\delta^{18} \mathrm{O}$ profiles. Groundwater, 47(5): 639-645.

Hunkeler D, Aravena R, Berry-Spark K, Cox E (2005) Assessment of Degradation Pathways in an Aquifer with Mixed Chlorinated Hydrocarbon Contamination Using Stable Isotope Analysis. Environmental Science \& Technology, 39(16): 5975-5981.

Jones JAA (2011) Sustaining groundwater resources: a critical element in the global water crisis, International year of Planet Earth. Springer, The Netherlands, 228 pp.

Liu F, Williams MW, Caine N (2004) Source waters and flow paths in an alpine catchment, Colorado Front Range, United States. Water Resources Research, 40(9): W09401.

Liu Y, Yamanaka T (2012) Tracing groundwater recharge sources in a mountain-plain transitional area using stable isotopes and hydrochemistry. Journal of Hydrology, 464-465(0): 116-126.

Misstear BDR, Brown L, Daly D (2009) A methodology for making initial estimates of groundwater recharge from groundwater vulnerability mapping. Hydrogeology Journal, 17(2): 275-285.

Mizota C, Kusakabe K (1994) Spatial distribution of $\delta \mathrm{D}$ and $\delta^{18} \mathrm{O}$ values of surface and shallow groundwaters from Japan, south Korea and east China. Geochem. J., 28: 387-410.

Molinari FC et al. (2007) Risorse idriche sotterranee della Provincia di Ferrara. "Groundwater resources of the Ferrara Province". DB-MAP printer, Florence, Italy, pp. 1-62.

Morrison WE, Parker BL, Cherry JA (1998) Hydrogeological controls on flow and fate of PCE DNAPL in a fractured and layered clayey aquitard : a Borden experiment, Geological Society of America, annual meeting. Geological Society of America, Boulder, CO.

Nakaya S et al. (2007) Spatial separation of groundwater flow paths from a multi-flow system by a simple mixing model using stable isotopes of oxygen and hydrogen as natural tracers. Water Resources Research, 43(9): W09404.

Nelson DW, Sommers LE (1996) Methods of Soil Analysis. Part 3. Chemical Methods. Soil Science Society of America. Book Series no.5, pp. 961-1010.

Nijenhuis I, Kuntze K (2016) Anaerobic microbial dehalogenation of organohalides - state of the art and remediation strategies. Current Opinion in Biotechnology, 38: 33-38.

Nijenhuis I et al. (2013) A stable isotope approach for source apportionment of chlorinated ethene plumes at a complex multi-contamination events urban site. Journal of Contaminant Hydrology, 153(0): 92-105.

Parker BL, Cherry JA, Chapman SW (2004) Field study of TCE diffusion profiles below DNAPL to assess aquitard integrity. Journal of Contaminant Hydrology, 74(1-4): 197-230.

Parker BL, Cherry JA, Chapman SW, Guilbeault MA (2003) Review and analysis of chlorinated solvent DNAPL distributions in five sandy aquifers. Vadose Zone J 2: 116-137.

Pasini M, Gargini A, Aravena R, Hunkeler D (2008) Use of hydrogeological and geochemical methods to investigate the origin and fate of vinyl chloride in groundwater in an urban environment, Ferrara, Italy. In: M.G. Trefry (Editor), Groundwater quality: securing groundwater quality in urban and industrial environments IAHS Publication pp. 102-109. 
Pedretti D, Masetti M, Beretta GP, Vitiello M (2013) A Revised Conceptual Model to Reproduce the Distribution of Chlorinated Solvents in the Rho Aquifer (Italy). Groundwater Monitoring \& Remediation, 33(3): 69-77.

Pedretti D, Masetti M, Marangoni T, Beretta GP (2012) Slurry wall containment performance: monitoring and modeling of unsaturated and saturated flow. Environmental Monitoring and Assessment, 184(2): 607-624.

Qin D et al. (2011) Assessing impact of irrigation water on groundwater recharge and quality in arid environment using CFCs, tritium and stable isotopes, in the Zhangye Basin, Northwest China. Journal of Hydrology, 405(1-2): 194-208.

Regione Emilia-Romagna and ENI-AGIP (1998) Riserve idriche sotterranee della Regione Emilia-Romagna "Groundwater resources of the Emilia-Romagna Region”. S.EL.CA. printer, Florence.

Rietti-Shati M, Yam R, Karlen W, Shemesh A (2000) Stable isotope composition of tropical high-altitude fresh-waters on Mt. Kenya, Equatorial East Africa. Chemical Geology, 166(3-4): 341-350.

Rizzini A (1974) Holocene sedimentary cycle and heavy-mineral distribution, Romagna-Marche coastal plain, Italy. Sedimentary Geology, 11(1): 17-37.

Roberts RJ, Cherry JA, Schwartz FW (1982) A case study of a chemical spill: Polychlorinated biphenyls (PCBs): 1. History, distribution, and surface translocation. Water Resources Research, 18(3): 525-534.

Robins N (1998) Recharge: the key to groundwater pollution and aquifer vulnerability, In: Groundwater Pollution, Aquifer Recharge and Vulnerability. Geological Society Special Publications, London, pp. 1-5.

Schwartz FW, Cherry JA, Roberts JR (1982) A case study of a chemical spill: Polychlorinated biphenyls (PCBs): 2. Hydrogeological conditions and contaminant migration. Water Resources Research, 18(3): $535-545$.

Sherwood Lollar B et al. (2000) Stable Carbon Isotope Evidence for Intrinsic Bioremediation of Tetrachloroethene and Trichloroethene at Area 6, Dover Air Force Base. Environmental Science \& Technology, 35(2): 261-269.
Shouakar-Stash O, Frape SK, Drimmie RJ (2003) Stable hydrogen, carbon and chlorine isotope measurements of selected chlorinated organic solvents. Journal of Contaminant Hydrology, 60(3-4): 211-228.

Slater GF, Sherwood Lollar B, Sleep BE, Edwards EA (2001) Variability in Carbon Isotopic Fractionation during Biodegradation of Chlorinated Ethenes: Implications for Field Applications. Environmental Science \& Technology, 35(5): 901-907.

Stroo HF, Ward CH (2010) In situ remediation of chlorinated solvent plumes. Springer, New York, 802 pp.

Stumpp C, Hendry MJ (2012) Spatial and temporal dynamics of water flow and solute transport in a heterogeneous glacial till: The application of high-resolution profiles of $\delta^{18} \mathrm{O}$ and $\delta^{2} \mathrm{H}$ in pore waters. Journal of Hydrology, 438-439(0): 203-214.

Tockner K et al. (2008) Flood plains: Critically threatened ecosystems. In: N.V.C. Polunin (Editor), Aquatic ecosystems: trends and Global Prospects. Cambridge University Press, London, pp. 45-61.

Vogel TM, Criddle CS, McCarty PL (1987) Transformation of halogenated aliphatic compounds. Environ. Sci Technol, 21: 722-736.

Vrba J, Zaporozec A (1994) Guidebook on Mapping Groundwater Vulnerability, 16. IAH, Intern. Contrib. to Hydrogeology, Heise Verlag, Hannover.

Wassenaar LI, Hendry MJ, Chostner VL, Lis GP (2008) High resolution pore water $\delta^{2} \mathrm{H}$ and $\delta^{18} \mathrm{O}$ measurements by $\mathrm{H}_{2} \mathrm{O}$ (liquid)$\mathrm{H}_{2} \mathrm{O}$ (vapor) equilibration laser spectroscopy. Environ. Sci. Technol., 42(24): 9262 - 9267.

Weyhenmeyer CE, Burns SJ, Waber HN, Macumber PG, Matter A (2002) Isotope study of moisture sources, recharge areas, and groundwater flow paths within the eastern Batinah coastal plain, Sultanate of Oman. Water Resources Research, 38(10): 1184.

Wilcox WM, Solo-Gabriele HM, Sternberg LOR (2004) Use of stable isotopes to quantify flows between the Everglades and urban areas in Miami-Dade County Florida. Journal of Hydrology, 293(1-4): 1-19.
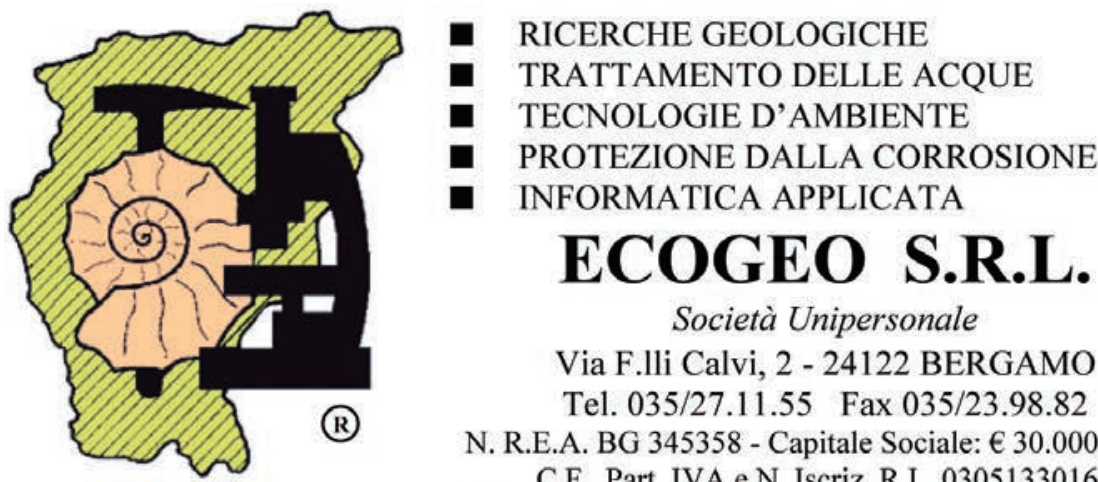

Società Unipersonale

Via F.lli Calvi, 2 - 24122 BERGAMO

Tel. 035/27.11.55 Fax 035/23.98.82

N. R.E.A. BG 345358 - Capitale Sociale: $€ 30.000,00$ i.v.

C.F. Part. IVA e N. Iscriz. R.I. 03051330169

http://www.ecogeo.net e-mail: info@ecogeo.net

Posta Elettronica Certificata: ecogeo@pec.ecogeo.net

\author{
LABORATORI D'ANALISI \\ SERVIZI D'INGEGNERIA \\ ARCHITETTURA \& DESIGN \\ ENERGIA E SVILUPPO SOSTENIBILE \\ SICUREZZA E IGIENE AMBIENTALE
}
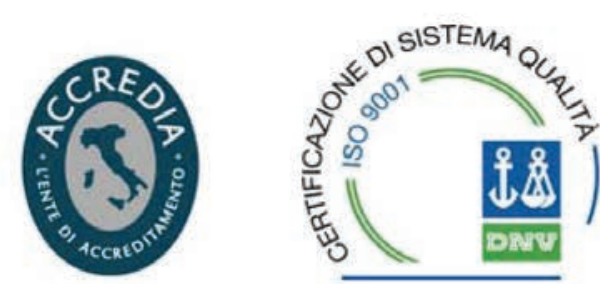